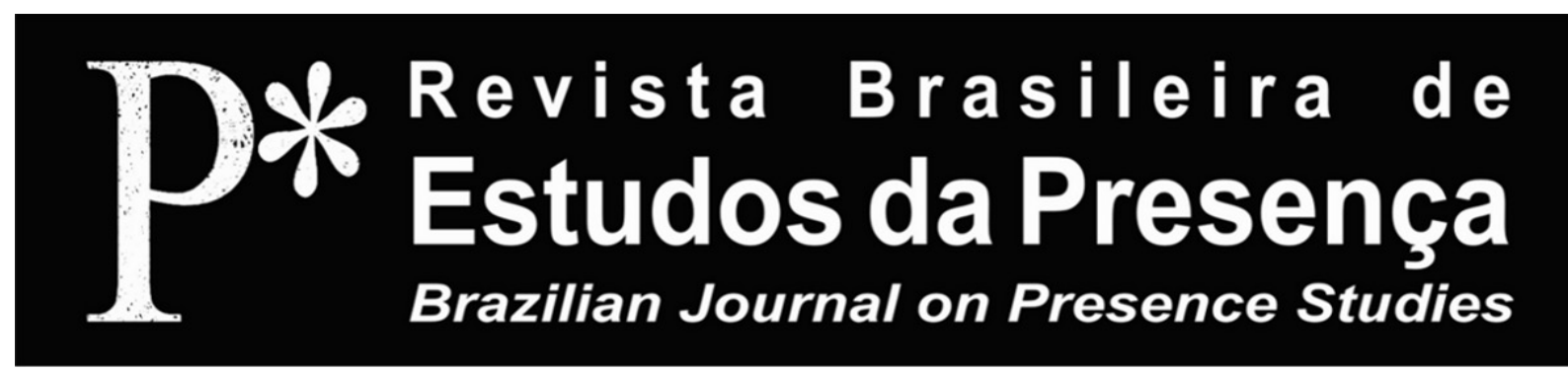

DOI - http://dx.doi.org/10.1590/2237-266037020

ISSN 2237-2660

\title{
Da Imagem à Cena: o palhaço fotógrafo e o registro do circo-teatro
}

\author{
Alda Fátima de Souza \\ Universidade do Sudoeste da Bahia - UESB, Jequié/BA, Brasil \\ Universidade Federal da Bahia - UFBA, Salvador/BA, Brasil
}

RESUMO - Da Imagem à Cena: o palhaço fotógrafo e o registro do circo-teatro - Este artigo trata do registro, a princípio registro fotográfico e depois escrito, realizado pelo palhaço Cadilac e evidencia a forma de atuação nos pequenos circos mambembes e o início de uma troupe circense, no período entre 1950 e 1970. A pesquisa, concluída em fevereiro de 2012, teve como resultado final a dissertação na área de Artes Cênicas intitulada $A$ memória do circo mambembe: o palhaço Cadilac e a reinvenção de uma tradição. Para a realização deste artigo, utilizou-se o levantamento da pesquisa, em que foram feitos cruzamentos de dados entre as entrevistas, documentos de arquivos públicos, fotos, escritos do próprio palhaço, além de diversas publicações sobre o assunto em questão.

Palavras-chave: Registro. Fotografia. Troupe. Circo. Teatro.

ABSTRACT - From the Image to the Scene: the photographer clown and the recording of the circus-theater - This article is about the recording, photographic at first and then written, accomplished by the clown Cadilac, and highlights the ways of acting in small "mambembe" circuses and the beginning of a circus troupe, in the period between 1950 and 1970. The research, completed in February 2012, had as its final result the thesis in the field of Performing Arts entitled The memory of the mambembe circus: the clown Cadilac and the reinvention of a tradition. For this article, a survey research was used, with data crossing between interviews, documents from public archives, photos, the clown's own writings, beyond several publications on the subject.

Keywords: Register. Photography. Troupe. Circus. Theater.

RÉSUMÉ - De l'Image à la Scène: le clown photographe et l'archivage du cirquethéâtre - Cet article traite de l'archivage et de la conservation, notamment photographique mais aussi écrite, faite par le clown Cadilac. Il permet d'appréhender le jeu circacien dans le contexte des petits cirques itinérants ainsi que le début d'une troupe de cirque dans une période située entre 1950 et 1970 . L'enquête, réalisée en février 2012, a abouti à la rédaction d'un mémoire dans le domaine des arts du spectacle intitulé La mémoire du cirque itinérante: le clown Cadilac et la réinvention de la tradition. Cet article s'appuie sur les interviews, documents d'archives, photos, es écrits personnels du clown et aussi sur des publications existantes autour de ce sujet, procédant à un croisement des données.

Mots-clés: Archives. Photographie. Troupe. Cirque. Théâtre. 


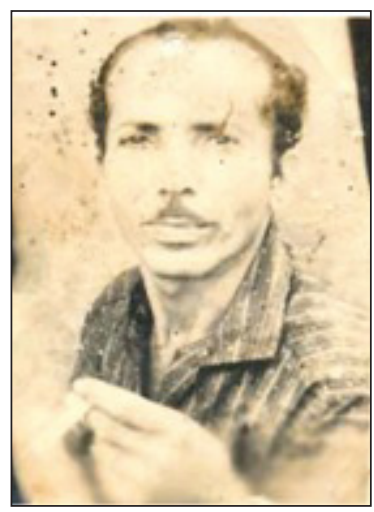

Imagem 1 - João Francisco Silva, o Cadilac. Aracaju, década de 1950. Fotografia: Euclides (provavelmente). Acervo de Jucineide Silva.

O registro escrito das atividades circenses no Brasil não é algo tâo incomum, mas, dentre esses registros, é difícil achar questóes específicas sobre a atuaçáo dos circos no Nordeste brasileiro, e, quando se restringe à técnica do palhaço, isso se torna mais difícil ainda. Em termos de pesquisa em Artes Cênicas, principalmente sobre a atuação dos circos, são muito recentes os levantamentos de técnicas dos espetáculos, os métodos de aprendizagem dos números e os dados históricos, sendo este último, também, o termo cujas informaçóes são mais difíceis de encontrar quando falamos de circos nordestinos. Foi a falta de documentação histórica e artística que conduziu esta pesquisa.

Este artigo aborda a trajetória circense de João Francisco Silva (1921-2002), nascido no Catende, Pernambuco, e a forma empírica ${ }^{1}$ que serviu de base para a constituição desta, a partir da técnica da fotografia. Filho de Maria Lopes da Silva e Francisco Antônio da Silva, oriundo de família humilde, não imaginava que, um dia, viria a ser o palhaço Cadilac e que daria início a toda uma geraçáo de artistas circenses.

Foi a partir do contato com o material que constitui o acervo da família Silva, inicialmente guardado por Cadilac e posteriormente por seus filhos e a sua viúva, que foi possível identificar fotos e documentos que haviam colaborado na reconstruçáo de parte de uma história circense pouco difundida no Brasil. A dificuldade de encontrar referenciais teóricos, sejam acadêmicos ou outros tipos de publicaçóes do período de 1950 a 1980, que pudessem contrapor os documentos escritos, os registros fotográficos e os manuscritos da família Silva evidenciou que a principal fonte de pesquisa seria as 
entrevistas realizadas com os artistas descendentes de Cadilac, que ainda guardavam, em sua memória, toda a oralidade transmitida de geração a geração (Verena, 2005). Essas entrevistas foram comparadas entre si, com os documentos que compunham o acervo da família e com os referenciais teóricos ora encontrados, com o objetivo de organizar datas, fatos e atividades artísticas em um período marcado por restriçóes, altas taxas de analfabetismo, censuras e pouca valorização da arte circense. $\mathrm{O}$ Brasil sofreu com todos esses problemas e o Nordeste também, conforme menciona Ruy Bartholo. Segundo o autor, por volta de 1940, “[...] o norte e o nordeste, por falta de estradas regulares, eram considerados outros países” (1999, p. 24). Os circenses nas décadas de 1950 e 1960 eram desbravadores, conforme relatado nas entrevistas, pois andavam a pé em lugares que náo possuíam nem mesmo vias para qualquer tipo de transporte.

Na década de 1940, na cidade de Recife, Pernambuco, João aprendeu a técnica da fotografia e estabeleceu uma sociedade com um fotógrafo de nome Euclides, que passou a ser seu compadre, levando-o para a cidade de Aracaju, em Sergipe, com o propósito de adquirirem um espaço próprio para exercerem a profissão. Em Aracaju, na década de 1950 , João exercia o ofício de fotografar com maestria em todas as suas etapas: fotografar, revelar, cortar e entregar. Kubrusly (2006, p. 9) afirma que "[...] ser fotógrafo é um pouco como ingressar num clube privado onde só alguns eleitos são admitidos”. Parece que João foi admitido nesse clube privado, pois era dessa técnica que extraía sua fonte de renda, assim como foi ela a causa de sua inserção no meio circense. Instalou-se juntamente com sua família em um local chamado Beco dos Cocos, no centro da cidade, para que ele pudesse ficar mais próximo da Praça da Bandeira, conhecida também como Praça dos Oitis, onde os fotógrafos ambulantes instalavam suas barracas. Exerceu a profissão de fotógrafo nessa praça durante quatro anos.

João Silva, assim como outros fotógrafos, era conhecido como jardim $^{2}$ ou lambe-lambe ${ }^{3}$. Eles, mesmo sem noção da importância que tinham para a sociedade naquele período, exerciam uma profissão que acabou por ter como incumbência o registro, a memória de toda uma geração, a cultura e o relato de uma sociedade em um vasto país que dificilmente investia em tecnologia. A técnica aprimorada amadoramente ao longo dos anos deixa de ser conhecida como 
retrato e passa a ser fotografia no final do século XIX ${ }^{4}$. A câmera de lambe-lambe era artesanal, construída pelo próprio fotógrafo, feita a partir de uma caixa de madeira e tecido (Fernandes Júnior, 2009, p. 2). A câmera de João também era assim e, até aproximadamente a década de 1990, pouco antes do seu falecimento, ele ainda registrava as fotos da família com a sua câmera artesanal, na qual, através da emulsão e incidência da luz, ocorriam os efeitos químicos necessários à reprodução de uma imagem captada em uma chapa.

Para Barthes (1984, p. 77-78), a fotografia vai além de um simples efeito químico, pois "[...] o que a ação química desenvolve é o indesenvolvível, uma essência (de ferida), o que náo pode transformar-se, mas apenas repetir-se sob as espécies da insistência (do olhar insistente)". Não cabe, neste artigo, analisar as fotografias produzidas por João Silva, mas sim tratá-las, neste caso, como uma referência documental, de forma a não poder "[...] negar que a coisa esteve lá" (1984, p. 115, grifo da autora).

Assim, a técnica da fotografia executada por João Silva perpassou todo o período da sua atividade circense e, de acordo com seu filho José Alfredo, mesmo quando estava itinerando como troupe ou com algum circo, João adquiria e estocava as emulsóes, papéis fotográficos e outros materiais necessários para continuar exercendo essa técnica, inclusive nos vilarejos onde não era possível encontrálos. É dessa forma - e, mesmo sem se dar conta da importância desse registro, muito mais por uma paixáo pela arte de fotografar - que João Silva começa a registrar os pequenos circos no interior de Sergipe na década de 1950.

Jucineide afirma que seu pai, João Silva, não conhecia nenhum circo até entrar em contato com o circo do palhaço Tarugo. Confrontando essa afirmativa, realizei algumas pesquisas em jornais da época na cidade de Aracaju, onde foi possível comprovar que, nesse período, o único grande circo que passou em Aracaju foi o Circo Nerino5, que ousadamente realizou uma grande turnê pelo Brasil, passando por diversas capitais, inclusive Aracaju, entre 24 de janeiro e 20 de fevereiro de 1950. É provável que João não tivesse acesso a esse circo durante sua temporada em Aracaju, pois se tratava de um espetáculo feito para pessoas de certo poder aquisitivo, o que não era o seu caso. As matérias encontradas no jornal Correio de Aracaju estavam localizadas nas páginas dos anunciantes, sendo provável que 
fossem matérias pagas. Mesmo depois da estreia do circo na cidade, as matérias continuavam a sair nas páginas dos anunciantes, porém divulgando o tipo de espetáculo: Variedades na primeira parte e um Drama ou Comédia na segunda parte ${ }^{6}$. Por isso, o primeiro contato que João Silva teve com as artes circenses foi através de um circo pano de roda no interior de Sergipe, quando prestava serviços de fotógrafo nas cidades do interior com o objetivo de aumentar a sua renda. Joáo fazia da profissão de fotógrafo uma arte que o acompanhava a todo instante. Por isso, de acordo com as entrevistas realizadas, não deixava a câmera um só momento, levando-a sempre pendurada nas costas. Dessa forma, sempre registrava os melhores momentos de um evento, de uma família e, mais tarde, dos circos, fazendo dessa atividade sua principal fonte de renda. Mesmo quando percebeu que itinerar com o circo era sua grande paixão, ainda assim não deixou de exercer a arte da fotografia. Assim, foi em uma destas vezes que João estava com sua câmera lambe-lambe nas costas que passou em frente ao circo e foi abordado pelo dono. Interrogado se era retratista, ele respondeu que sim e que era preto e branco. Na década de 1950, as fotografias mais utilizadas pelos profissionais eram em preto e branco ${ }^{7}$. As fotos eram, muitas vezes, coloridas manualmente após a revelação, por isso, quando João mencionou ser retratista preto e branco, ele quis dizer que não utilizava nenhum recurso para colorir as fotos.

O palhaço Tarugo ficou empolgado por haver encontrado um retratista para fotografar suas filhas, que também eram artistas, tendo, assim, a possibilidade de aumentar a renda do circo através da venda das fotos ao público que o frequentava. Vale ressaltar que somente circos maiores conseguiam registrar seus artistas e, assim, transformar estes retratos em lembranças vendidas no próprio circo. A imagem era posada, não sendo possível imagem em movimento, ou seja, de um número circense realizado pelo artista. Assim, João foi bem recebido no meio circense por dominar a técnica da fotografia e poder registrar os artistas circenses, capturar suas imagens, eternizá-las e depois comercializá-las.

Com a arte da fotografia, João inicia o registro da memória de pequenos circos e da sua própria família. A princípio, esse registro acontece através da imagem. Mais tarde, a partir de uma necessidade de um registro escrito daquilo que era transmitido oralmente, ele começa a reescrever peças e comédias. 
Ao se dirigir para o interior de Sergipe, João buscava o povo humilde, pensando, assim, em aumentar sua renda oferecendo seus serviços de fotógrafo, mas acabou encontrando o circo e entáo percebeu o quanto era mais rentável tirar fotos dos artistas para que estes as vendessem. Na sua primeira inserção no circo, tirou mais de 100 fotos e, na mesma hora, já as revelou, recortou e entregou. $\mathrm{O}$ dono do circo lhe disse que, naquele momento, não tinha dinheiro para pagá-lo, mas que, assim que vendesse as fotos, pagaria aquelas e tiraria outras. João confiou, pois começou a ficar encantado com a arte circense que até entáo desconhecia. Nas semanas que se seguiram, João voltou diversas vezes ao circo do palhaço Tarugo, sempre aos fins de semana. Foi através desse dono de circo que ele conheceu outros, aumentando sua clientela circense.

Após o falecimento da sua esposa na cidade de Aracaju, João vendeu os poucos pertences que tinha, pegou um carro de boi ${ }^{8} \mathrm{e}$ viajou para o circo do Tarugo. Foi a partir dessa decisão de Joáo Francisco que se iniciou uma nova família circense.

João se insere no contexto circense a partir da sua habilidade de fotografar, por isso ele é bem aceito em um espaço simbólico, destinado somente aos iniciados (Silva, 2009) na arte circense, permitindo a ele e a seus filhos passarem pelo ritual:

$\mathrm{O}$ acesso à tradição era estendido àqueles que não nasciam no circo, mas que a ele se incorporavam: o requerimento era a passagem pelo ritual de aprendizagem ministrado por uma das famílias tradicionais, corroborado pela passagem de seus filhos pelo mesmo ritual, agora ministrado por ele mesmo, da mesma forma que recebeu. Este 'estranho' poderia ser então considerado um tradicional, um formador da tradicional família circense ou um formador de uma dinastia circense (Silva, 2009, p. 89).

Após ter passado pelo ritual circense, Joáo pôde constituir sua própria geração de artistas circenses. Uma vez inseridos nesse universo, João e seus descendentes se tornaram uma família tradicional na arte circense, tendo "[...] recebido e transmitido, através das geraçóes, os valores, conhecimentos e práticas, resgatando o saber circense de seus antepassados" (Silva, 1996, p. 56).

Atualmente a família já está na terceira geração e todos são considerados no meio circense como tradicionais, excluindo toda e qualquer possibilidade de um dia alguém dessa família ter fixado 
residência em uma cidade ou em outro local que não fosse o circo. Mesmo aqueles que hoje fixaram residência em alguma cidade ainda se consideram tradicionais circenses, pois detêm o conhecimento da arte que lhes foi transmitida de pai para filho.

João reinventa para si e sua família uma forma de transmissão da arte circense, focando, na construção do palhaço, as habilidades e técnicas, adquiridas empiricamente nos pequenos circos nos quais se inseriu. A transmissão desse conhecimento, a partir da sua reinvenção às próximas geraçôes, só foi possível uma vez que reuniu:

[...] um conjunto de práticas, normalmente reguladas por regras tácitas ou abertamente aceitas; tais práticas, de natureza ritual ou simbólica, visam inculcar certos valores e normas de comportamento através da repetição, o que implica, automaticamente, uma continuidade em relação ao passado (Hobsbawm, 1997, p. 9).

Dessa forma, a reinvenção da arte na vida de João trata, de uma forma muito peculiar, de transmitir oral e corporalmente técnicas tradicionalmente enraizadas no universo circense.

Durante o ano de 1954, Joáo e seus filhos percorreram algumas cidades dos estados de Sergipe (Capela e Tobias Barreto) e Bahia (Itapicuru, Olindina, Nova Soure, Caldas de Cipó, Ribeira do Pombal, Cícero Dantas, Nova Serra, Antas, Jeremoabo e Paulo Afonso). Na cidade de Paulo Afonso, fora do circo do Tarugo, ele retorna às atividades de fotógrafo para conseguir dinheiro e manter a sua família. Sua então companheira, Josefa, com a pouca experiência que adquiriu no circo do palhaço Tarugo, retoma os treinamentos de contorção com as filhas de João, enquanto os filhos aprendem números aéreos. Como náo possuíam equipamentos de segurança, material raro nesse período, na casa alugada, cobriram o chão de areia para amortecer qualquer queda que porventura ocorresse durante os ensaios.

Viajando muitas vezes a pé, em carro de boi, em pau de arara ou marinete 9 , João e sua família percorreram diversas cidades após a saída de Paulo Afonso, em direção ao pequeno vilarejo onde Josefa nasceu, chamado Pau de Feijão, na zona rural de Caldas de Cipó, na Bahia. Foram 207 quilômetros percorridos sob condições precárias até chegar ao vilarejo, quando então Josefa propôs a João que fizessem uma apresentaçáo e que ele fosse o palhaço, passando ela a mestrar cena ${ }^{10}$ para ele. $\mathrm{O}$ primeiro nome de palhaço de João foi Gostosinho, escolhido por Josefa. A apresentação ocorreu na sala 
da casa da mãe de Josefa, sendo o pequeno espetáculo divulgado de porta em porta ${ }^{11}$ para avisar que haveria espetáculo naquela noite, à luz de candeeiro. Apresentaram cantorias, Jucineide, filha de João, fez número de contorção, e, no momento da entrada do palhaço, Joáo, ainda sem coragem de entrar em cena e assumir a posição de palhaço, pediu que seu filho José Alfredo fosse buscar uma cachaça, pois, apesar de não beber, necessitava, naquele momento, de um estímulo. Ele tomou de um gole só a cachaça, quando ouviu Josefa do local da apresentação chamá-lo:

- Vem trabalhar, Gostosinho!

Ele então responde:

- Você quer que eu entre como? Chorando ou cantando?

Ela fala:

- Cantando [...] $]^{12}$

Assim começa a trajetória do futuro palhaço Cadilac.

O espetáculo montado com essa nova troupe começou a itinerar pelos pequenos vilarejos, apresentando-se nas salas das casas ou em locais onde fosse possível reunir um grupo de pessoas. Em entrevista, José Alfredo menciona que o espetáculo, quando iniciaram a troupe, era muito precário e só era possível se apresentar nas zonas rurais, onde não havia nenhum tipo de entretenimento, nem mesmo luz elétrica, de forma que, sob a luz do candeeiro, tudo parecia perfeito. Assim tinha início a Troupe dos Silva ${ }^{13}$, que começava a itinerar com seus pequenos espetáculos circenses.

Cada cidade, povoado ou vilarejo tinha uma peculiaridade: havia locais em que eram bem recebidos, em outros, nem tanto; em alguns, conseguiam apresentar os números circenses, em outros, somente as cantorias e serenatas que Josefa interpretava. Havia lugares onde os fazendeiros da regiáo compravam os espetáculos para que fossem apresentados nas suas fazendas. Até em casa de farinha ${ }^{14}$ se apresentaram, de acordo com informaçóes de Jucineide. Em outros lugares, os açougueiros trocavam espetáculos por carne e, assim, realizavam escambos com a arte circense. Além do interior da Bahia, a troupe percorreu Sergipe e Alagoas e, mais tarde, já em circos de terceiros, o estado de Pernambuco. Ao mesmo tempo em que apresentavam seus espetáculos, realizavam outras atividades nas cidades por onde passavam. Jucineide e José Alfredo mencionam que saíam de um circo e iam andando a pé até encontrar uma fazenda ou um 
vilarejo onde pudessem vender seus espetáculos. Não carregavam nada, somente a roupa do corpo, nem sapatos tinham. Quando chegavam a um local onde pudessem apresentar os espetáculos, arrancavam madeiras do mato, fincavam-nas no terreno, pegavam cobertores surrados doados pela populaçáo para circundar as toras de madeira e ali estava armado um pano de roda. As pessoas, além de pagarem pelos ingressos, levavam suas próprias cadeiras, ficavam em pé ou sentavam no chão. Jucineide afirma que achava bonito ver no final do espetáculo aquela fila de gente que seguia para suas casas com as cadeiras na cabeça.

Também se apresentavam no que é denominado de tapa-becos. Jucineide explica que eram espaços entre duas casas, fechados em um lado e, no outro, utilizavam uma cortina por onde o público entrava. Ali realizavam os seus números e shows, convidavam um sanfoneiro ou um pandeirista e animavam a vida das pessoas da localidade. Joáo usava uma estratégia para atrair o público: quando eles se apresentavam nesses tapa-becos, ele começava a gritar:

- Mulher, coloca logo a roupa, que o show vai começar ${ }^{15}$

Assim, o público corria achando que ainda iria pegar a artista nua naquele pequeno espaço no qual eram feitas tanto as trocas de roupas quanto a apresentação. A descrição desse tapa-beco corresponde à mesma dada por Silva (2009, p. 123): "Um terreno baldio, ladeado por duas casas, recebia na frente e no fundo uma cobertura, como uma cortina de tecido de algodão".

Ao passo que foram aperfeiçoando as técnicas circenses, realizavam os números de contorção, palhaço, equilíbrio em tamborete, escada de copo, trapézio de copo, cantavam bolero, dançavam rumba e Josefa ainda cantava músicas de Luiz Gonzaga, que, na época, era o ícone da música nordestina. Jucineide diz que, quando seu pai, Joáo, já possuía seu próprio circo, ela ganhava mais dinheiro passando fita ${ }^{16}$ do que seu pai conseguia na bilheteria ou entáo quando pediam e colocavam dinheiro no picadeiro para que ela repetisse uma posiçáo do número de contorção: uma bandeira, uma escala ou uma ponte. Por vezes, os artistas eram contratados para realizar serestas nas fazendas depois dos espetáculos.

A realidade social e econômica do Nordeste no período em questão, década de 1950, na qual a população sofria com a seca, miséria, precariedade de recursos financeiros, falta de acesso ao ensino formal, 
entre outras problemáticas no âmbito urbano e principalmente rural, influenciou diretamente no tipo de espetáculo circense realizado pela Troupe dos Silva, pois este estava inserido nesse contexto social, bem como na forma de pagamento desses espetáculos ${ }^{17}$.

A organização do circo, nos diferentes lugares para os quais os artistas migraram, foi marcada pelas relaçôes singulares estabelecidas com as realidades culturais sociais específicas de cada região ou país, sem quebrar a forma de transmissão do saber: familiar, coletiva e oral. Esta forma perdura praticamente até os dias de hoje, particularmente nos grupos circenses itinerantes da lona (Silva, 2009, p. 25).

Por diversas vezes, a Troupe dos Silva trabalhou em outros circos, como, por exemplo, o Circo do Almeida e o It Variedades, que pertencia a Alínio, mais conhecido como palhaço Chuvisco. Como criaram grande amizade com Alínio, sempre saíam e voltavam a trabalhar em seu circo. O circo do palhaço Chuvisco mais tarde recebeu o nome de Azes Pernambucanos ${ }^{18}$.

Por volta de 1958, cerca de dois anos após o início da itinerância com a Troupe dos Silva, Josefa abandonou essa família na cidade de Santo Amaro, na Bahia, e João e seus três filhos continuaram a trabalhar em circos de terceiros, economizando dinheiro com o objetivo de comprar material para o seu próprio circo. Com os primeiros recursos financeiros que a Troupe dos Silva conseguiu, criou um pequeno circo pano de roda que recebeu o nome de Lírio da Noite.

O circo Lírio da Noite era um pano de roda, com cerca de madeira, ladeado de panos de saca de farinha. Nos dois mastros centrais, ficava a corneta, que chamava o público e anunciava o espetáculo, além de aparelhos aéreos como o trapézio. Esses mastros, por serem mais altos que o pano de roda, deixavam os aparelhos aéreos à vista das pessoas que estavam do lado de fora do circo, que, assim, normalmente assistiam ao menos aos números aéreos. Mas, de acordo com Jucineide e José Alfredo, isso não tirava a magia do circo e normalmente instigava o público a ver todo o espetáculo do lado de dentro do circo.

Por volta de 1961, João passa a ter Luzinete como companheira, aquela que ficaria com ele até o seu falecimento, tendo inclusive mais onze filhos, o que contribuiu na formação das próximas geraçóes circenses. João, já com os filhos adolescentes e realizando diversos números circenses, itinera por vários estados do Nordeste. 
Ainda como pano de roda, o circo recebe, então, diversos nomes: Leal Bahia, Lunar, Pindorama e, mais tarde, já com cobertura, Iquiloni Circo, sendo este último já administrado por José Alfredo, o Zinho, e sua esposa, Lúcia.

A criação do palhaço Cadilac só foi possível por volta de 1962, quando João Silva entregou a administração do circo para seu filho José Alfredo. É a partir desta dedicação ao palhaço que João inicia uma trajetória de ensinamentos aos filhos, netos, bisnetos e amigos.

Com o circo Iquiloni, percorreram o interior de Sergipe, Alagoas, Pernambuco, Bahia e Minas Gerais. Neste último estado, o circo passou a ser conhecido como Washington Circus. Após anos de vivência e prática das artes, seja em outros circos, em pequenas cidades, em vilarejos, como troupe, em circo-pavilhão, circo-tourada ou circo-cinema (Araújo, 1981), conhecendo inúmeros artistas de circos, grandes ou pequenos, a família Silva se firma com seu próprio circo. No circo Iquiloni, foi possível realizar números como: a Escada Giratória, Double Escada, Double Trapézio, Giro da Morte, Contorção e espetáculos de Circo-Teatro, além da participação de artistas nacionalmente famosos como: Zé do Rancho e Mariazinha ${ }^{19} \mathrm{e}$ Cascatinha e Inhana ${ }^{20}$. Tomando como referência a pesquisa de Maria Tereza Vargas, realizada em Sáo Paulo, Circo de periferia, na qual ela realiza uma classificação entre circos de pequeno, médio e grande porte, de acordo com a quantidade de público capaz de lotar o circo, percebe-se que a estrutura do circo Iquiloni já se configurava como um circo de pequeno porte, possuindo cobertura e uma capacidade para 300 pessoas por espetáculo. Esse circo-família também cresceu, pois, além de haver a esposa de João, Luzinete, José Alfredo se casa com Lúcia, Jucineide se casa com Irênio (mais tarde, palhaço Miúdo) e Jurineide também se casa com Manoel Gomes (palhaço Gibi). Jurineide, porém, alguns anos após seu casamento, não se dedica mais à vida circense. Basicamente, dentro dessa estrutura circense existiam quatro núcleos familiares, que foram se ramificando e gerando outros núcleos. Após a consolidação do circo Iquiloni, outras famílias de artistas foram sendo agregadas, como foi o caso de Antônio Alceno, que se configurou como um parceiro para o palhaço Cadilac, sendo chamado de palhaço Calhambeque.

Por ter o conhecimento da escrita e da leitura, João, em diversos circos nos quais atuou, passou a ser $o$ ponto nas representações de dramas e demais peças teatrais encenadas na época. Suas habilidades 




como fotógrafo lhe possibilitaram ter um olhar apurado com relação ao posicionamento dos atores frente ao público, e foi essa capacidade de observação que levou João a se tornar o ensaiador dessas peças teatrais, além de ser o ponto. É através da realização dessas funçôes nos circos que João passa a reconhecer a importância do registro escrito das peças que encenava.

Nos textos transcritos por João, fica evidente que este possuía uma boa caligrafia, apesar de alguns erros ortográficos. Ele os copiava com esmero e mencionava que eles foram transcritos, assim como indicava o autor, quando conhecido. Quando já estava bem velho, solicitava aos filhos mais novos que transcrevessem um pouco para ele, por isso, nos textos pesquisados, há páginas que têm sua caligrafia, enquanto em outras há a caligrafia de seus filhos.

Não foi possível digitalizar os textos na íntegra devido ao estado de conservação, mas há páginas digitalizadas, evidenciando trechos das seguintes peças: Trágica Noite de Natal; A Marca do Pecado; Jesus e a Samaritana; Maconha, a Erva Maldita; ...O Céu Uniu Dois Coraçôes; Um Erro Judiciário - O Louco da Aldeia; O Mundo Não me Quis; Rosas de Nossa Senhora; e Ah! Se o Anacleto Soubesse. Ainda há outras peças cuja digitalização náo foi possível ser realizada, porém há indícios de suas encenaçôes, conforme apontadas nas entrevistas com Jucineide e Luzinete: Lágrimas de Mãe; A Louca do Jardim; Filho de Ninguém; O Milagre de Santa Terezinha; O Homem que Revoltou-se Contra Deus; Escrava Isaura; e Jerônimo O Herói do Sertão.

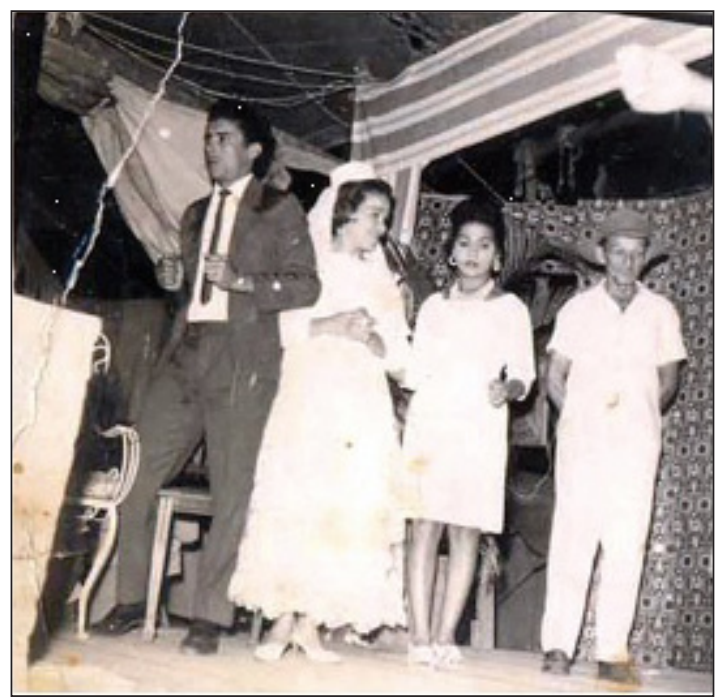

Imagem 2 - Circo Iquiloni, década de 1960. Fotografia: João Silva. Acervo Jucineide Silva. 
A princípio, João organizava a encenação e transmitia, de forma oral, as falas de cada personagem, pois muitos não sabiam ler ou escrever, por isso, durante os ensaios, as falas eram ditas por ele. Com o passar dos anos, todos os artistas já sabiam o que devia ser feito no picadeiro e as falas de seus personagens de acordo com as peças encenadas. Vale salientar que, nas transcriçóes de Joáo, não há indicação do ano em que ocorreu a encenação, pois compunha o repertório de circo-teatro, realizado pelo circo Iquiloni, mesmo quando este possuía outros nomes, conforme apontado anteriormente.

Dentre os documentos guardados por Gilson, filho de João com Luzinete, está um texto datilografado que foi entregue a João por José Bartholo, dono do Bartholo Circus, atribuindo a autoria a J. Silva ${ }^{21}$, na cidade de Teófilo Otoni, com a data de 14 de setembro de 1957. Apesar de indicar o ano de 1957, Luzinete náo lembra exatamente quando foi que João recebeu esse texto de José Bartholo. As informaçóes acima mencionadas aparecem na primeira página, a qual não foi possível digitalizar devido ao estado de conservação das folhas de papel.

Optou-se por não realizar uma comparação mais aprofundada do conteúdo dos textos transcritos por João com outros documentos de referência, uma vez que essa análise não é o principal foco desta pesquisa.

As peças encenadas pelo circo, com o nome de Iquiloni e, mais tarde, como Washington Circus, sempre tinham um fundo moral, suscitavam questóes polêmicas (homossexualidade, preconceitos, tabus), falavam de amores impossíveis, reforçavam a dicotomia entre o bem e o mal e falavam de padróes e costumes de uma época. Os dramas sacros reforçavam a fé católica de um povo, realizando releituras dramatúrgicas sobre a Bíblia. A partir das inovações tecnológicas ocorridas na década de 1980, o cotidiano, mesmo das comunidades rurais, começa a se modificar. Esta modificação ocorre a partir da "[...] abertura da economia de cada país aos mercados globais e a processos de integração regional [...]" (Canclini, 1995, p. 140). É a partir dessa ruptura que o "papel das culturas nacionais" foi reduzindo. Nesse processo de urbanizaçáo e modernização do país, os costumes locais se veem ameaçados e passam por um processo de adaptação ao mundo globalizado, "nas redes globalizadas de produção e circulação simbólicas se estabelecem as tendências e os estilos das artes, das linhas editoriais, da publicidade e da moda" 
(Canclini, 1995, p. 141). Dessa forma, a plasticidade do espetáculo circense, a forma de representar dos atores do circo-teatro e toda a produção do espetáculo passam a ser comparadas com a programaçáo da televisão, por exemplo. Por isso, a partir de 1980, o Washington Circus realizou seus últimos espetáculos de circo-teatro (A Paixão de Cristo), passando a atuar somente como circo de variedades.

O circo-teatro ainda é foco da atuação de alguns circos no Brasil, como, por exemplo, o Circo do Biriba (Bolognesi, 2003), porém aqueles que descendem do palhaço Cadilac não possuem mais, em seu repertório, as peças de circo-teatro, somente variedades, comédias e esquetes cômicas. Outros circos pesquisados durante o projeto $O$ circo e suas técnicas: a importância da arte circense na formação do ator, de 2000 a 2002, também já não possuíam peças de circo-teatro em seus repertórios. Outra fonte de pesquisa é o Mapeamento e memória do circo na Bahia ${ }^{22}$, realizado pelo Núcleo de Artes Circenses da Fundação Cultural do Estado da Bahia, entre 2007 e 2010, sob minha coordenação, no qual não foram encontrados circos que atuassem com peças de circo-teatro. Por isso, dentre os circos itinerantes pesquisados na Bahia no período compreendido entre 2000 e 2011, náo havia e não há, em seus repertórios, as peças de circo-teatro, apesar de alguns circenses conhecerem-nas na forma oral.

\section{Consideraçóes Finais}

A vida circense, instigante, aventureira e desafiadora, aliada à necessidade de criar os filhos, atraiu Cadilac, que se inseriu nessa tradição através da técnica da fotografia. Essa técnica foi a grande responsável pela sua aceitaçáo e de seus familiares nos circos que percorriam o interior de Sergipe na década de 1950, pois somente os grandes circos tinham o privilégio de terem seus artistas fotografados, transformando essas fotografias em lembranças vendidas ao público das cidades por onde passavam. É a partir da decisão de adentrar no universo circense que Cadilac reinventa para si e para sua família um novo modo de vida, deixando de ser morador fixo em uma cidade para ser itinerante, apropriando-se de uma tradição que náo lhe pertencia de fato, mudando, assim, todo o curso das próximas geraçóes de sua família.

A profissão de fotógrafo possibilitou a Cadilac aprimorar um olhar atento, treinado, para o qual cada gesto ou açáo eram percep- 
tíveis à câmera. Ele aprendeu a registrar, através da fotografia, aquilo que mais lhe interessava: um olhar, um gesto, uma pessoa, uma ação, uma família; elementos como um painel de fundo, a luz, as cores, as formas contribuíam na obtenção de uma imagem melhor. A maneira de se posicionar diante da câmera também favorecia o capturar dessa imagem.

É esse olhar apurado que conduz Cadilac a perceber os elementos e técnicas necessários à arte circense quando se insere nessa tradição, tecendo principalmente observaçóes acerca da arte do palhaço.

Os registros fotográficos, bem como alguns poucos escritos, disponibilizados para esta pesquisa náo constituem um vasto material, porém é admirável ver que uma troupe ou um pequeno circo nas décadas de 1950 e 1960 registrava o próprio ofício, fato que só ocorria em grandes circos, por artistas que detinham certo grau de conhecimento ou aqueles que possuíam recursos financeiros para isso.

No período de itinerância da Troupe dos Silva, os pequenos circos e troupes viviam à margem da sociedade. Por isso, não se encontraram registros em jornais, revistas ou materiais impressos nesse período sobre a Troupe dos Silva ou o circo Iquiloni. Sabe-se, segundo os relatos dos entrevistados, que havia diversos circos e troupes que atuavam nas zonas rurais mais distantes da faixa litorânea do Nordeste, porém ainda não há registros sobre esses circos. Esperase, então, estimular outras pesquisas que evidenciem esses pequenos circos, capazes de conduzir um espetáculo circense em lugares onde, ainda hoje, não há nenhuma outra forma de lazer e entretenimento. 


\section{( \\ Estudos da Presenca

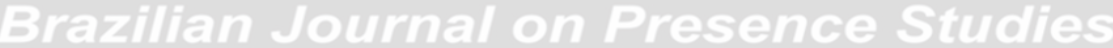

\section{Notas}

${ }^{1} \mathrm{O}$ empirismo é a escola do pensamento filosófico relacionada à teoria do conhecimento, que pensa estar, na experiência, a origem de todas as ideias. Para esta pesquisa, a palavra empírica e suas derivaçôes se referem às experiências ou práticas dos artistas.

${ }^{2}$ Os fotógrafos que atuavam nas praças ficaram conhecidos como fotógrafos de jardim por utilizarem painéis pintados com paisagens no fundo de suas fotografias.

${ }^{3}$ Eram assim conhecidos por molharem a ponta do dedo para verificar de que lado estava a emulsão na chapa. Ver mais em Fernandes Júnior (2009, p. 2).

${ }^{4}$ História da fotografia disponível em: <http://www.girafamania.com.br/montagem/ fotografia-brasill.htm>. Acesso em: mai. 2011.

${ }^{5}$ Ver Avanzi; Tamaoki (2004, p. 194).

${ }^{6}$ Esta forma de subdivisão do espetáculo praticada já na década de 1950 pelo circo Nerino também era adotada pelos pequenos circos. Assim, em 1954, quando João se inseriu nas atividades circenses, os espetáculos já eram realizados neste formato. A divisão entre primeira e segunda parte do espetáculo circense se perpetua até os dias de hoje, porém nem sempre ocorrem dramatizaçôes na segunda parte.

${ }^{7}$ História da fotografia disponível em: <http://www.girafamania.com.br/montagem/ fotografia-brasill.htm>. Acesso em: mai. 2011.

${ }^{8}$ Meio de transporte muito utilizado na época.

${ }^{9}$ Carro de boi, pau de arara e marinete, tipos de transportes muito utilizados pelos nordestinos. O primeiro era muito usado nas zonas rurais, sendo carroças puxadas por bois; o segundo era muito usado nas estradas para levar imigrantes nordestinos para o sudeste do país e consistia em um caminhão que possuía diversas varas na sua carroceria nas quais as pessoas se penduravam ou colocavam seus pertences; o terceiro era o nome popular de diversos onibus que circulavam nas cidades e interior do Nordeste.

${ }^{10}$ Termo usado pelos circenses para designar a ação do Mestre de Cena. Mestre de Cena, também conhecido como mestre de pista, crom, escada ou clown, forma dupla cômica com o palhaço. O Mestre de Cena, ao contrário do clown, por exemplo, não utiliza nenhuma maquiagem ou roupa que o caracterize. Nos pequenos circos, o Mestre de Cena pode ser o próprio apresentador do espetáculo.

${ }^{11}$ Forma de divulgar os espetáculos nos vilarejos, na qual os artistas se dirigiam à casa das pessoas, batiam à porta e anunciavam que haveria espetáculo, informando o horário, local e valor.

${ }^{12}$ Trecho do diálogo entre Josefa e Joáo Silva, de acordo com a entrevista realizada com a filha de João, Jucineide Silva, no dia 07 de agosto de 2010.

13 "Entenda-se 'troupe' como um grupo de artistas que em dado momento se desmembra do elenco semi-estável em que atuava e passa a gerir a própria existência, num modesto circuito de salas em prédios escolares, cinemas, clubes e mercados, explorando um repertório de dramas, comédias e farsas (a 'segunda parte'), complementado ou não com uma 'primeira parte’ de variedades, ou lançando mão apenas desta última” (Araújo, 1979, p. 14).

${ }^{14}$ Local onde se processa a farinha de mandioca. 
${ }^{15}$ Fala de João Silva, de acordo com a entrevista realizada com sua filha, Jucineide Silva, no dia 07 de agosto de 2010.

${ }^{16}$ Após realizar um número, a artista se dirigia a uma pessoa do público, normalmente homens, e passava, em seu ombro, um lenço ou pano: pagando em dinheiro, o número circense era repetido, caso náo pagasse, ela se dirigia a outra pessoa.

${ }^{17}$ Em locais em que o dinheiro circulava, cobravam-se ingressos; naqueles em que não circulava, realizavam-se trocas. De qualquer forma, o espetáculo não deixava de acontecer.

${ }^{18} \mathrm{Na}$ pesquisa de Nélson de Araújo no Recôncavo Baiano, foi realizada uma entrevista com Alino Fonseca, dono do circo Azes Pernambucanos. Trata-se do mesmo artista.

${ }^{19} \mathrm{Ver}<$ http://www.boamusicaricardinho.com/zedorancho_41.html>. Acesso em: mai. 2011. ${ }^{20} \mathrm{Ver}<\mathrm{http}: / /$ www.dicionariompb.com.br/cascatinha-e-inhana/dados-artisticos>. Acesso em: mai. 2011.

${ }^{21}$ Este autor teve uma coletânea com 36 peças lançada no dia 29 de agosto de 2011, em Minas Gerais, através da pesquisa de Sula Mavrudis.

22 Disponível em: <http://www.fundacaocultural.ba.gov.br/projetos/mapeamento-ememoria-do-circo-da-bahia>. Acesso em: 31 jan. 2013.

\section{Referências}

ALBERTI, Verena. Manual de História Oral. 3. ed. Rio de Janeiro: FGV, 2005.

ARAÚJO, Nelson de. Duas Formas de Teatro Popular no Recôncavo Baiano. Salvador: O Vice-Rey, 1979.

ARAÚJO, Nelson de. História do Teatro. Salvador: EGBA, 1991.

ARAÚJO, Vicente de Paula. Salóes, Circos e Cinemas de São Paulo. São Paulo: Perspectiva, 1981.

AVANZI, Roger; TAMAOKI, Verônica. Circo Nerino. São Paulo: Selo Pindorama Circus/ Codex, 2004.

BAKHTIN, Mikhail Mikhailovich. A Cultura Popular na Idade Média e no Renascimento: o contexto de François Rabelais. 4. ed. São Paulo/Brasília: Hucitec/UnB, 1999.

BARTHES, Roland. A Câmara Clara: nota sobre a fotografia. Rio de Janeiro: Nova Fronteira, 1984.

BARTHOLO, Ruy. Respeitável Público: os bastidores do fascinante mundo do circo. Rio de Janeiro: Letras \& Expressóes, 1999.

BERGSON, Henri. O Riso: ensaio sobre a significação do cômico. Rio de Janeiro: Jorge Zahar, 2004.

BOLOGNESI, Mário. Circos e Palhaços Brasileiros. São Paulo: Cultura Acadêmica, 2009. BOLOGNESI, Mário. Palhaços. São Paulo: UNESP, 2003.

BURKE, Peter. Cultura Popular na Idade Moderna: Europa 1500-1800. São Paulo: Companhia das Letras, 2010. 
CAMARGO, Robson Corrêa. A Pantomima e o Teatro de Feira na Formaçáo do Espetáculo Teatral: o texto espetacular e o palimpsesto. Goiânia: UFG/Fênix Revista de História e Estudos Culturais, 2006.

CANCLINI, Nestor Garcia. Consumidores e Cidadáos. Rio de Janeiro: UFRJ, 1995.

CEDRAN, Lourdes et al. O Circo. São Paulo: Secretaria da Cultura e Tecnologia/Paço das Artes, 1978.

CORREIO DE ARACAJU. Aracaju. Exemplares do jornal do período 1950-1954.

COSTA, Eliene Benício Amâncio. Saltimbancos Urbanos: a influência do circo na renovação do teatro brasileiro nas décadas de 80 e 90. 1999. 717 f. Tese (Doutorado em Artes Cênicas) - Programa de Pós-Graduação em Artes Cênicas, Escola de Comunicações e Artes, Universidade de São Paulo, São Paulo, 1999.

A CRUZADA. Aracaju: Diocese Católica de Aracaju, p. 4, 22 out. 1950. (E outros exemplares do jornal não citados diretamente no texto).

DUARTE, Regina Horta. Noites Circenses: espetáculos de circo e teatro em Minas Gerais no século XIX. Campinas: Unicamp, 1995.

DUVIGNAUD, Jean. Festas e Civilizaçóes. Rio de Janeiro: Tempo Brasileiro, 1983.

FERNANDES JÚNIOR, Rubens. Desconhecidos Íntimos: o imaginário do fotógrafo lambe-lambe. São Paulo: FAAP/FACOM, 2009.

FO, Dario; RAME, Franca. Manual Mínimo do Ator. 2. ed. São Paulo: SENAC, 1999.

FRÓES, Leonardo. Os Lambe-Lambe. In: Coisas Nossas. Rio de Janeiro: Secretaria de Estado de Educação e Cultura e Mec-Funarte, 1978.

GOUVÊA, Isabel. Lambe-lambe: resistindo à extinção. Jornal FotoBahia, Salvador, n. 1, p. 3, jul. 1981.

HOBSBAWM, Eric J. Introdução: a invenção das tradições. In: HOBSBAWM, Eric; RANGER, Terence (Org.). A Invençáo das Tradiçóes. 2. ed. Rio de Janeiro: Paz e Terra, 1997. P. 9-23. Coleção Pensamento e Crítica, v. 55.

KUBRUSLY, Cláudio Araújo. O que é Fotografia. São Paulo: Brasiliense, 2006. Coleção Primeiros Passos, v. 82.

LOUREIRO, Clóvis. A Linguagem da Fotografia. São Paulo: [199-]. Texto avulso.

MAGNANI, José Guilherme Cantor. Festa no Pedaço: cultura popular e lazer na cidade de São Paulo. São Paulo: Brasiliense, 1984.

MIliTEllO, Dirce Tangará. Picadeiro. São Paulo: Guarida Produções, 1978.

MILITELLO, Dirce Tangará. Terceiro Sinal. São Paulo: Mercury Produções Artísticas Ltda., 1984.

MINOIS, Georges. História do Riso e do Escárnio. São Paulo: UNESP, 2003.

NORONHA, Paulo. O Circo. v. 1. São Paulo: Academia de Letras de São Paulo, Cena: Brasil - v. I, 1948.

NOVELLI JÚNIOR, João Batista (Org.). Circo Paulistano: arquitetura nômade. São Paulo: IDART, 1980. (Pesquisa 09.) 
O CIRCO e suas Técnicas: a importância da arte circense na formação do ator. II SEMINÁRIO DE PESQUISA E PÓS-GRADUAÇÁO E XX SEMINÁRIO ESTUDANTIL DE PESQUISA, 2002, Salvador. Anais... Salvador: Pró-Reitoria de Pesquisa e Pós-graduação da Universidade Federal da Bahia, 2002. P. 266.

PANTANO, Andréia Aparecida. A Personagem Palhaço. São Paulo: UNESP, 2007.

PAVIS, Patrice. Dicionário de Teatro. São Paulo: Perspectiva, 1999.

PROPP, Vladimir Iakovlevich. Comicidade e Riso. São Paulo: Ática, 1992.

RUIZ, Roberto. Hoje tem Espetáculo? As origens do circo no Brasil. Rio de Janeiro: INACEN, 1987.

SEYSSEL, Waldemar. Arrelia: uma autobiografia. São Paulo: IBRASA, 1997.

SILVA, Cleberson Macedo. Entrevistadora: Alda Souza. Mucugê, BA, 13 fev. 2011. MP3.

SILVA, Ermínia. Respeitável Público... o circo em cena. Rio de Janeiro: Funarte, 2009.

SILVA, José Alfredo. Entrevistadora: Alda Souza. Olindina, BA, 16 jan. 2011. MP3.

SILVA, José Fernandes. Entrevistadora: Alda Souza. Araripe, CE, 20 fev. 2011. MP3.

SILVA, José Wellington. Entrevistadora: Alda Souza. Campos Sales, CE, 19 fev. 2011. MP3.

SILVA, Jucineide Conceição. Entrevistadora: Alda Souza. Dias d’Ávila, BA, 7 ago. 2010. MP3.

SILVA, Maria Luzinete. Entrevistadora: Alda Souza. Guarapari, ES, 28 fev. 2011. MP3.

SILVA, Wilson Barros. Entrevistadora: Alda Souza. Boquim, SE, 06 fev. 2011. MP3.

SOUZA, Alda Fátima de. A Memória do Circo Mambembe: o palhaço Cadilac e a reinvenção de uma tradição. 2012. Dissertação (Mestrado em Artes Cênicas) - Programa de Pós-graduação em Artes Cênicas, PPGAC - Escola de Teatro, Universidade Federal da Bahia, Salvador, 2012.

TORRES, Antônio. O Circo no Brasil. Rio de Janeiro: Funarte, 1998.

VARGAS, Maria Thereza (Org.). Circo: espetáculo de periferia. São Paulo: IDART, 1981.

Alda Fátima de Souza possui graduação na área de Licenciatura em Teatro pela Universidade Federal da Bahia (2005) e Mestrado em Artes Cênicas pelo Programa de Pós-graduação da Escola de Teatro da UFBA (2012). Foi coordenadora do Núcleo de Artes Circenses da Fundação Cultural do Estado da Bahia, no período de 2008-2013. Atualmente, leciona na Universidade Sudoeste da Bahia - UESB, na cadeia de História do Teatro e Teatro/Educação. Participa do Grupo de Trabalho de Etnocenologia, com publicaçóes de artigos nos Congressos da Associação Brasileira de Pesquisa e Pós-graduação em Artes Cênicas (ABRACE) desde 2010. Publicou o artigo Cortejo Circense: trajeto festivo no Cadernos do GIPE-CIT, ano 14, número 26, 2011.

E-mail: aldasouza.laborda@gmail.com 